\title{
SOME FEATURES OF SOCIAL COGNITION AND EXPERIENCE OF THE EAST AND WEST
}

\author{
${ }^{1}$ A.U. Nussipova, ${ }^{2}$ B.A. Nuralina
}

\section{ABSTRACT}

In modern domestic and foreign literature, quite intensive research is being carried out in the field of features and differences in the development of East and West. Especially the East. This is because for a long time the majority of Europeans have knowledge of the East for a number of reasons limited by rather superficial ideas. If in the days of antiquity, they just started talking about the fact that "despotism and barbarism" is inherent in the East, and then in the 14th century in European thought this idea was already formulated in the form of the concept of "Asian despotism", which was closely associated with the lack of private property and legal guarantees of the person. This kind of general interest is far from accidental: the end of the 20th century. With its gloomy apocalyptic clouds hanging over the planet, it prompts many to seriously become interested in both existential problems (which arouse active attention to mysticism, and here the indisputable priority is given to ancient cultures and religions of the East), and the search for roots, primary sources. According to these initial data, society naturally developed.

Keywords: Despotism, Barbarism, Domination, Social Being, Space.
1,2Abai Kazakh National
Pedagogical University,
Almaty, Kazakhstan

Author-correspondent:

B.A. Nuralina, botanur@mail.ru

Reference to this article:

Nussipova A.U.,

Nuralina B.A. Some Features

of Social Cognition and

Experience of the East and

West // Adam alemi. - 2021.

- No. 2 (87). - P. 81-89.

\section{Шығыс пен Батыстың әлеуметтік танымы мен тәжірибелерінің кейбір ерекшеліктері}

Аннотация. Қазіргі отандық және шетелдік әдебиеттерде Шығыс пен Батыстың даму ерекшеліктері мен айырмашылықтары саласында айтарлықтай қарқынды зерттеулер жүргізілуде. Әсіресе Шығыста, бұл ұзақ уақыт бойы еуропалықтардың Шығыс туралы білімінің көпшілігі бірқатар себептерге байланысты тек үстірт идеялармен шектелгендігімен байланысты. Егер ежелгі дәуірде олар «деспотизм мен варваризм» Шығысқа тән деп айта бастаса, онда XIV ғасырда еуропалық ойда бұл идея «азиялық деспотизм» тұжырымдамасы түрінде қарастырылды, ол жеке меншіктің және тұлғаның құқықтық кепілдіктерінің болмауымен тығыз байланысты. Жалпы қызығушылықтың бұл түрі кездейсоқтықтан алыс: XX ғасырдың аяғы. бұлыңғыр бұлтпен планетаның үстінде ілулі болғандықтан, көптеген адамдар экзистенциалдық проблемаларға (мистикаға белсенді назар аударатын және мұнда шығыстың ежелгі мәдениеттері мен діндері үшін басымдылық бар) және іздеудің маңызды мәселелеріне ақпарат көздеріне қызығушылық танытуға итермелейді. Осы алғашқы мәліметтерге сәйкес қоғам табиғи түрде қалыптасты.

Түйін сөздер: деспотизм, варварлық, үстемдік, әлеуметтік болмыс, кеңістік 


\title{
Некоторые особенности социального познания и опыта Востока и Запада
}

\begin{abstract}
Аннотация. В современной отечественной и зарубежной литературе ведутся достаточно интенсивные изыскания в области особенностей и различия развития Востока и Запада. Особенно Востока. Это вызвано тем, что долгое время у большинства европейцев знания о Востоке в силу ряда причин ограничивались достаточно поверхностными представлениями. Если во времена античности только начали говорить о том, что Востоку присущ «деспотизм и варварство», то в XIV веке в европейской мысли эта идея уже была сформулирована в виде концепции «азиатского деспотизма», которая тесно связывалась с отсутствием частной собственности и правовых гарантий личности. Такого рода всеобщий интерес далеко не случаен: конец XX в. с его нависшими над планетой мрачно-апокалиптическими тучами побуждает многих всерьез заинтересоваться как экзистенциальными проблемами (которые пробуждают активное внимание к мистике, а здесь бесспорный приоритет за древними культурами и религиями Востока), так и поисками корней, первоистоков. По этим первоначальным данным, естественно, сложилось общество.
\end{abstract}

Ключевые слова: деспотизм, варварство, господство, социальное бытие, космос

\section{Introduction}

If in the days of antiquity, they just started talking about the fact that "despotism and barbarism" is inherent in the East, and then in the 14th century in European thought this idea was already formulated in the form of the concept of "Asian despotism", which was closely associated with the lack of private property and legal guarantees of the individual. Starting from the 16th century, the Ottoman Empire began to be considered a symbol of this kind of state structure, with the absolute power of the Sultan and the arbitrariness of the administration characteristic of it.

In modern times, Charles Montesquieu's words that "Europe is the genius of freedom, and Asia the spirit of slavery" and Herder's comparison that China is an embalmed mummy wrapped in silk and painted with hieroglyphs were widely known. Similar ideas existed in the works of J. St. Mill and most Western economists of the time. To these arrogant and dismissive assessments given to the East by famous people of Europe, we can add the statement of the German philosopher Ge1, who, so to speak, summed up the theoretical justification of the backwardness and underdevelopment of the East. According to Hegel, the highest form and genuine guarantee of freedom is the European state contemporary to this philosopher with its constitution and human rights. His theory is based on the following view. The whole story is the process of man gaining more and more freedom. Therefore, the goal of world history is to know oneself by the world spirit. Humanity, developing, comes to an ever-deeper understanding of freedom.

In this regard, Hegel divides the whole story into three great eras. The first is the Eastern era (the era of Ancient India, China, Egypt, etc.) - where people still do not realize freedom, people here meekly obey either the authority of the father in the family, or the authority of the emperor in the state. In this society, only one person enjoys freedom and all the blessings of life - the emperor, pharaoh, etc., and all the rest are his slaves and servants. The greatest resonance in Europe was received by Max Weber's theory (1864-1920), which distinguished several civilizational types of society, each of which is more or less predisposed to economic development [1, 101 p]. Weber correlated this predisposition, first, with the religious and social views of this society and directly linked the source of Western economic progress with the religious ideas of the reformation.

\section{East and West: Principles of Life within the Framework of Cognitive Orientations}

According to Weber, the "ideal capitalist type" corresponds to Protestant ethics, alien not only to Asian civilizations, but also significantly different from other Christian 
faiths: from Catholicism and even more so from Orthodoxy. Weber contrasted Protestantism with Confucianism, stressing in every way that economic progress is impossible in Confucian society.

It is very curious that in recent years, when the economic successes of East Asian countries have become evident, a whole series of works has appeared, the authors of which are trying to either refute or modify Weber's theory. Moreover, the successes of China, Japan, Korea and other countries of East and Southeast Asia are often explained precisely by the Confucian mentality and Confucian ethics [2, p. 300].

In general terms, "interest in the East these days is huge and, apparently, will increase. This interest is comprehensive and all encompassing: history and culture, society and the state, man and religion (gods and people), and finally, the ancient fundamental principles of the great civilizations of the East. All this is now in the focus of attention both of the inhabitants of the East, aspiring to self-knowledge and self-identification, to discover the fundamental foundations of their own being, and even more so representatives of a different, Western, European tradition, whose general parameters are so different from the Eastern ones. This kind of general interest is far from accidental: the end of the 20th century. With its gloomy apocalyptic clouds hanging over the planet, it prompts many to seriously become interested in both existential problems (which arouse active attention to mysticism, and here the indisputable priority is given to ancient cultures and religions of the East), and the search for roots, primary sources. In addition, much in the modern world is closely connected with the East - it is enough to recall the phenomenon of developing countries with their most acute economic, demographic and sociocultural problems, whose solutions have not yet been found. How and when these problems will be resolved, what are the ways leading to their solution - all this worries and cannot but worry the world, the vast majority of whose population, which is growing both absolutely and relatively, lives precisely in developing countries, primarily, in the countries of the East" [3, p. 435].

What is the East? And what is the West? Since when has human society divided into East and West? What are their features and how do they differ from each other? Let us cite the statements of Russian scientists quite well known to the scientific community - P.Ya. Chaadayev, A.S. Panarin and L.S. Vasiliev. According to M.Ya. Chaadayev: "The world was originally divided into two parts - East and West. This is not only a geographical division, but also the order of things, due to the very nature of a rational being: these are two principles that correspond to the two dynamic forces of nature, two ideas that embrace the entire life order of the human race. Concentrating, deepening, closing in on himself, the human mind was created in the East; opening outward, radiating himself in all directions, struggling with all obstacles, he is developing in the West. According to these initial data, society naturally developed.

In the East, thought, deepening in itself, having gone into silence, hiding in the desert, provided public authority with the disposal of all the blessings of the earth; in the West, the idea, rushing everywhere, intervening for all the needs of man, hungering for happiness in all its forms, founded power on the principle of law. Nevertheless, in both areas, life was strong and fruitful; here and there the human mind did not lack in high inspirations, deep thoughts and exalted creatures. The East came first and poured streams of light onto the earth from the depths of its solitary contemplation; then the West came with its all-encompassing activity, with its living word and omnipotent analysis, took possession of its labors, finished the work of the East, and finally absorbed it in its wide girth" [4, p. 23].

A.S. Reflecting on these issues, Panarin asks: "Can we speak of the East as a single entity, or is this word just a metaphor for consciousness that seeks out exoticism and is full of Western orders? What lies behind this concept? The sum of regional and religious studies as indology, sinology, arabistics or some kind of interdisciplinary 
synthesis, which has under it a real community of countries and cultures of the East? In his opinion, "this concept reflects some real common dominants of Eastern culture, which are represented with different strength and clarity in various civilizations of the East - Indo-Buddhist, Confucian-Buddhist (Far Eastern), Muslim" [5, p. 145].

According to JIS. Vasiliev, who is undoubtedly one of the most respected Russian orientalists, in the meaning of the East, "we are not talking about a geographical concept, but rather a historical-cultural, socio-political, civilizational ... This is a gigantic universal humanity, albeit in something very heterogeneous and contradictory, but still almost monolithically solid in its deepest foundation - the very foundation that, in fact, gave rise to the East-West dichotomy in its time. But how did this dichotomy arise and what ultimately gave rise to it? In his opinion, "approximately in the IV - II millennia BC on Earth laid the foundations of a command and administrative structure. At the same time, primitive communal societies followed the same path. Then, approximately in the VII century. BC, bifurcation began in the Mediterranean, and as a result of not quite clear processes, something like a social mutation occurred and the phenomenon of antiquity arose" [6, p. 156]. A.S. Panarin adheres to the same hypothesis. He also believes that around the VII century. BC. There is an East-West dichotomy. This difference, according to the scientist, is determined by how these cultures disposed of the historical freedom that was born at the moment of transition from the mythological state of culture to the post-mythological one. Prior to this transition, in the primary "broth" of culture, which is a myth, the difference between the West and the East is not visible. But the transition itself includes a moment of bifurcation (bifurcation), which gave an impetus to two opposite trends in world culture. They could be illustrated symbolically using the biographies of the eldest and youngest son. Here Panarin refers to a figurative comparison given by J. Needam in his famous work, "Society and Science in the East and in the West." According to
J. Nidam, both brothers formed in a traditional patriarchal family, and came of age with an approximately equal burden of tradition. But the elder will have to stay in the family as an assistant to the father - with the prospect of inheritance of his property and role, and the younger decided to break with his native home, went to the city to seek a free share. In the first, the biography is dominated by a moment of responsible succession, which fetters freedom, but at the same time gives a guarantee, while the second is dominated by the moment of uninhibited freedom, inseparable from risk. The house and the burden of tradition weighs on the former; on the latter, uncertainty and the need to dodge, refine, and invent.

\section{Features of Social Cognition and Experience of the East and West}

As a result, we get two great cultural types - conservative and innovative, each of which carries its own complexes, its one-sidedness, its own burden of imperfection, inseparable from the sinful share of man in the world. The complex of the Western "youngest son" is an ego complex of guilt associated with an abandoned patrimonial center and inevitable violations of its moral commandments. The complex of the eastern "eldest son" is a complex of a provincial who, even believing in his moral superiority and righteousness, suffers from his alienation, from non-participation in the chaotic but alluring creativity of the unknown future, which for some reason cannot be created on the spot, without betrayal by relation to tradition. Here, says A.S. Panaria, we, perhaps, have found a keyword denoting a complex of the Western type of culture - this is cultural betrayal as a specific crime of civilization [7, p. 449]. The ethical logo itself, which has replaced the myth, bears a betrayal of anthropocentric arbitrariness in relation to the highest order of the universe, a person falling out of the system of cosmic harmony, self-expressed in myth. So, the Tao of oriental culture means a program alternative to the Western logos: not a consistent distance of a person from 
the harmony of the Cosmos, not an individualistically irresponsible emancipation, but on the contrary, a person's reverse aspiration for natural harmony.

According to this hypothesis, the whole subsequent history of humankind was a period of coexistence of these two opposing social structures. Moreover, the difference between them was not only in the elements, but also in the dynamics of evolution. European antique structure was characterized by mobility. It was on the basis of Greek antiquity that impressive successes were achieved in Ancient Rome in the fields of economics, political administration, and culture. According to this hypothesis, the whole subsequent history of humankind was a period of coexistence of these two opposing social structures. Moreover, the difference between them was not only in the elements, but also in the dynamics of evolution. European antique structure was characterized by mobility. It was on the basis of Greek antiquity that impressive successes were achieved in Ancient Rome in the fields of economics, political administration, and culture. Noting the unconditional advantages of Western civilization in a number of areas of human existence, it is necessary, in our opinion, to remember the flaws and shortcomings of this civilization, which can become tragic if you do not pay attention to it in time and offer an alternative. But in order for the alternatives to remain at the disposal of humankind, it is not necessary to uproot its cultural and civilizational diversity, it is not necessary to look for the complete and final victories of one civilization over all others [8, p. 24]. Here, a hidden historical and anthropological meaning of the "bipolar" structure of humankind as a sociocultural system divided into East and West is revealed. To clarify this situation, we will make a small digression into the field of psychology, to explain the specifics and features of the activity of the cerebral hemispheres, and on its basis to explain the meaning of the "bipolar" structure of humanity as a sociocultural system and its division into East and West.

According to Sperry's theory, the difference between the right and left hemispheres is determined by the characteristics of the information that each hemisphere perceives and processes; the left hemisphere is specialized in operating with verbal and other formal and symbolic material, and the right hemisphere is sensual images of real objects. In the studies of scientists, it is confirmed that each hemisphere is capable of processing both figurative and symbolic information. Apparently, it is important here that it is subjected to simultaneous or sequential assimilation, and it is not a matter of the formal belonging of the information to the symbolic or figurative, but some other of its characteristics. It has been shown that artist's process information based mainly on the possibilities of right-hemisphere thinking, and scientists - on the possibilities of left-hemispheric thinking, although, of course, exceptions are possible

The right and left hemispheres are differently "inscribed" in the time coordinate. The activity of the right is mainly connected with reliance on events that took place in the past. The left hemisphere is oriented towards the future. In addition, in accordance with this theory, processes occur in the left hemisphere that can be described as linear and sequential thinking, while processes of holistic perception occur in the right hemisphere [9, p. 10]. In its most general form, we can say that the right hemisphere is more associated with the motivational components of emotions, and the left with informational components. The Russian scientist Nefedov gives in his book the general principles of the structure of matter and the psyche based on the activity of the cerebral hemispheres. Compensation for strongly expressed individualism in the East is developed social consciousness in the form of ethical concepts of Confucianism, Taoism, Buddhism, etc. But, despite the large regulatory role of these ethical concepts, the gap between the individual and the public consciousness remains traditional. Evidence of this can be the existence of a dual existence in the East: daytime - public and nightly - individual.

What prevails in their ratio is difficult to say. This depends on the inclinations 
of each person, because some prefer daytime, social being, while others prefer nightly, individual being, trying in every possible way to free themselves from the futile vanity of the day and quickly plunge into the night element of individual freedom" [10, p. 42]. To understand how this tradition of thinking has developed, we will make a short historical digression. To begin with, what modern man creates within the framework of the classical paradigm of European culture? It is based on Aristotelian logic and the Cartesian dichotomy of man - the world. The current (formal) logic that underlies European thinking began around 2500 years ago. Its creator was the great ancient Greek philosopher from Stagira Aristotle. It is known that during this period in Greece there was a struggle between two opposing philosophical camps, one of which was headed by Aristotle and the other by Heraclitus. This struggle was a struggle between two worldviews, two logics - formal and dialectic, two methods of cognition of the world - science-like and intuitive-mystical, and two types of thinking - linear and nonlinear.

The greatest representative of Greek philosophy, whose logic formed the basis of European civilization, believed in a reductionist approach: if you break something down into its component parts, you can understand how it works. According to the thinker, everything has its own boundaries; everything can be localized and categorized. Being the founder of formal logic and the creator of syllogistics, Aristotle essentially seduced the world, saying that if you don't know something, ask those who know. The opponent of Aristotle Heraclitus held a different point of view the Dark of Ephesus. He, in contrast to Stagirith, said that the Universe is in constant motion, that stability and homeostasis are not the norm. One of the most famous and memorable sayings states: "Everything flows and everything changes. You cannot enter the same river twice" [10, p. 42]. For example, the roots of the educational system, when the unquestioned authority of the teacher dominates the personality of the student in all aspects, sprout from Aristotle's phi- losophy. Modern science is also based on the logic and philosophy of this thinker. In particular, following this philosophy, causal concepts, laws of motion, conservation of energy, and an increase in entropy were developed.

Heraclitus believed that universal wisdom, the world logos, the fiery word spoke with his mouth, and he was convinced that he was open to the eternally tense and disturbing rhythm of life that defines the Law of life. In our opinion, it is important to note, "Heraclitus presented his opinion of the universe in the form of mystical reasoning based on priestly traditions. Here he follows the example of the Pythagoreans, who organized themselves into mystical fraternities like Orphics" [6, p. 103]. It is quite obvious that the philosophy of this thinker expresses a more holistic, more harmonious and dialectical view of the world, which, unfortunately, was not in demand at the time, and only many centuries later reveals its huge cognitive potential, especially in the context of the latest discoveries of modern science. It is now obvious that this dispute between Aristotle and Heraclitus in its consequences is much more dramatic than a conflict regarding the structure of the Universe. It was a struggle of two worldviews, a struggle of two logics, a struggle of two methods of knowing the world, on the outcome of which, ultimately, the fate of humankind was dependent. Since Aristotle won this intellectual war, our life is what it is today. If Heraclitus won, then we would have a completely different civilization. Almost all of our thoughts, any type of analysis that we use is a consequence of the influence of Aristotle [11, p. 351]. The scientific method, inherited from Aristotle and loudly proclaimed by Bacon, has become the generally accepted method of scientific research and discovery.

After the discovery of subatomic particles in quantum mechanics, our logical world disintegrated. It turned out those subatomic particles "behave" differently than, according to scientists, they should conduct. The basic principles began to crumble. Therefore, for example, Aristotle argued that an object could not be both 
" $A$ " and not " $A$ ". Quantum science has entered into a dispute with Aristotle. And many experiments have shown that certain objects may not be something at the same moment in time. It also turned out that velocities significantly exceeding the speed of light are possible. It was, for example, proved that an electron, moving at an incredible speed, could be in two places simultaneously. If you follow the old logic of Aristotle, it seems that there was a mysticism here. The real world of elementary particles and the Universe, it turns out, does not obey the classical laws, so carefully formulated by scientists, and is not explained by old, linear thinking. It is also impossible to explain and describe with old thinking the reality of such a plan as chaos and turbulence. This requires a non-linear, holistic, so to speak, more based on the right hemisphere thinking, which is more characteristic of the East.

The famous American scientist J. Glake, in his book on chaos, writes that science has been deceiving itself for centuries, ignoring the slightest deviations in the process of collecting data and conducting experiments. The phrase "measurement error" was used whenever data did not fit into the framework of a causal paradigm. Scientists began to limit their research to closed systems, even if they were possible only in artificial conditions, instead of solving the problems of open systems, life, and turbulence $[9$, p. 10]. A completely new word in science in this regard is the concept of the American scientist D. Bohm. The main fundamental feature of his cosmology is the assertion that reality is one, that it represents the indivisible integrity that underlies the entire Universe, the basis of matter and consciousness, providing the source material for all manifested entities and events, generating and controlling everything through constant communication with everything in the deep structure of the whole [9, p. 7]. According to Bohm, everything in the Universe is not only interconnected, but in reality, it is the same thing. According to his theory, consciousness and life (and, in essence, everything in the Universe) are sets coiled up in the universe.
Such a vision has amazing consequences: each piece of the hologram contains the entire universe. This means that every cell in our body already contains a coiled cosmos. These fundamental discoveries of modern science provide the basis for a deeper understanding of the nature of consciousness, which cannot be explained by the old theoretical baggage of knowledge. Now it is quite obvious that a new understanding of consciousness is possible only on the basis of a deep understanding of not only the latest achievements of modern quantum - relativistic physics and psychology, but also a creative understanding of the experience of thinking and wisdom of the East.

This is especially important because the modern picture of the world revealed by quantum physics, according to physicists themselves, seems to bring us closer to the perception of the world, which is unusually similar to the picture of the world of mystics of the East. Paying attention to this feature, the director of the International Institute of Theoretical and Applied Physics of Russia, Academician A.E. Akimov writes the following: "Everything that physics has now come to, practically without formulas, but in a meaningful way, is stated in the ancient Indian Vedic books. There were and still are two directions of cognition of Nature. One is represented by Western science, that is, knowledge that is obtained on the methodological basis that the West owns, that is, evidence, experiment, etc. The other is Eastern teachings and practices, that is, knowledge acquired externally by the esoteric way, in a state of, for example, meditation. Esoteric knowledge is not obtained, it is given to man. It turned out that at some stage, this esoteric path was lost, and another path was formed, extremely complex and slow. Over the past thousand years, following this path, we have come to the knowledge that was known in the East 3,000 years ago" [12, p. 189]. Thus, according to a Russian scientist, European culture and science did not adequately assess the most important aspects of human life. So spirituality, which has always been highly valued in the East, has not equalized irrational methods of obtaining knowledge 
with rational ones, rejected non-traditional ways of obtaining information, etc.

From here, it inevitably fell into a deadlock, the way out of which, according to some scientists, is simple. It has long been proclaimed the most wise and far-sighted thinkers of the East and West: it is necessary to combine intuitive and scientific knowledge, to equalize in the rights to the criterion of "truth" what is obtained as a result of insight, trance or influx, and what revealed an exact experiment and logical construction. Therefore, if the question is posed, which way of knowing the World is more correct - underlying the traditional sciences or serving as the basis of religion, mysticism or Eastern methods, then, according to Academician Akimov, there is reason to believe that the advantage of traditional sciences does not follow from anything. Moreover, science has lagged behind the "unscientific" worldviews. In the Western system of spirituality, the scientist-rationalistic and utilitarian-economic consciousness of an individualistic sense, which functions on the basis of the logic of not a holistic perception of the world, but its discursive-analytical taxonomy in groups, classes, clans, etc., gained predominant development. In this system, there is no unifying principle that has a spiritual and moral essence, because the driving force of the West, the source of its dynamism are the mercantile and economic interests of the individual. The basis of their implementation is the rivalry of individuals, groups, states, etc. with the use of violence aimed at crowding out or suppressing a competitor. Of course, these aspirations are combined with a focus on achieving high efficiency and professionalism, which found expression in the ethics of Protestantism, and then secured, economic practicality. Cold calculated rationalism combined with high efficiency and professionalism allowed the West to achieve a high level of economic development, which made possible the success of Western liberalism and democracy.

Such an effective and impressive development of the West was accompanied, however, by significant losses of many of the universal human social and cultural heritage. The spirit of humanity and spiritual self-realization has been removed from this rational and individualized world, the means of achieving which is not only practical economic activity, but also spiritual aspiration, which is largely associated with irrational, intuitively mystical ways of perceiving being. Due to the one-sidedness of the type of spirituality that has developed in the West, which he himself is aware of, he is constantly searching for those complementary principles that could somehow compensate for the limitations of their own spiritual resources by including new dimensions of consciousness that have been developed in eastern cultures [13, p. 547]. In the spiritual structures of eastern civilizations, irrational, contemplatively intuitive methods of comprehending the world, in which the unity of seemingly opposite principles is realized, turned out to be significant. A constant correlate of tendencies towards the hypertrophy of individualism in the East is the developed social consciousness in the form of ethical concepts of Confucianism, Taoism, and Buddhism.

\section{Conclusion}

The economic paradigm is an inevitable product of historical and cultural heritage. Since every culture has its own strengths and weaknesses, its institutions cannot change quickly and easily. Culture, worldview, value system take a long time to form and change for a long time.

Hence, success or failure in an economy cannot be determined by culture alone. Building or changing an economic system based on progressive elements of culture is the task of any society. And here the determining factor is not culture, but the desire of people to turn their society into a prosperous one. In a globalizing world, this cannot be done either in isolation from other cultures, or at the expense of other cultures.

\section{Reference}

1. Druckman D. Negotiations: social psychological perspectives. - Beverly Hills, Calif., Sage, 1977. - Pp. 86-121. 
2. Maddux R.B. Successful Negotiation. Kogan Page. - London, 1992, 285 p.

3. Hofstede G.H. Culture's Consequences: International Differences in Work-Related Values. Thousand Oaks, CA: Sage, 1980 (revised and expanded in 2001), $387 \mathrm{p}$.

4. Ronen S. and Shenkar O. Clustering Countries on Attitudinal Dimensions: A Review and Synthesis // Academy of Management Review. 1985, 10(3). - Pp. 435-454.

5. Schwartz S.H. A Theory of Cultural Values and Some Implications for Work // Applied Psychology, 1999, 48(1). - Pp. 23-47.

6. Peng Luo. Analysis of Cultural Differences between West and East in International Business Negotiation // International Journal of Business and Management. 2008, vol. 3, No. 11. - Pp. 103-106.

7. Adler Nancy J and Graham John L. Strategy Implementation: A comparison of face-to-face negotiations in the People's Republic of China // Strategic Management Journal. 1992. Vol 13, no 7. - Pp. 449-466.

\section{INFORMATION ABOUT AUTHORS}

\section{Botakoz Nuralina}

Arailym Nussipova

Ботакоз Амангелдикызы Нуралина

Арайлым Умарходжаевна Нусипова

Ботакөз Амангелдіқызы Нұралина

Арайлым Умарходжаевна Нусипова
8. Everett M. R., William B. H., Yoshitaka M., Edward T. Hall and The History of Intercultural Communication // The United States and Japan, Keio Communication Review. 2002. - No.24, 24 p.

9. Salacuse J.W. Ten Ways that Culture Affects Negotiating Style: Some Survey Results // Negotiation Journal. - 1998, 14. - Pp. 221240.

10. Lynn E. Metcalf. Cultural Influences in Negotiations, A Four Country Comparative Analysis. - Orfalea College of Business, Cal Poly State University. - 2005, p. 42.

11. Tohyama Yasuko. Aspects of Japanese Nonverbal Behavior in Relation to Traditional Culture // In Yoshihiko Ikegami (ed.), The Empire of Signs: Semiotic Essays on Japanese Culture. Amsterdam: John Benjamins, 2001, 351 p.

12. Faure G.et Rubin J. Culture and Negotiation. Newbury Park // Sage, 1993. - Pp. 7-189.

13. Plantey A. La négociation internationale. - Paris, Dunod, 1994. - Pp. 547-715. 